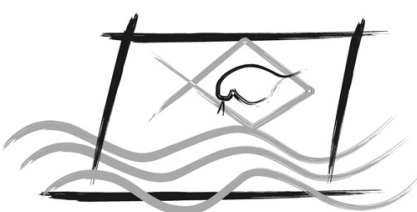

ECOTOX - BRASIL

\title{
Micronucleus test and comet assay in erythrocytes of the Amazonian electric fish Apteronotus bonapartii exposed to benzene
}

\author{
A. Bücker ${ }^{1}$, M.S. Carvalho ${ }^{1}$, M.B. Conceição $O^{2}$ \& J.A. Alves-Gomes ${ }^{1 *}$
}

\begin{abstract}
${ }^{1}$ Laboratório de Fisiologia Comportamental e Evolução (LFCE), Coordenação de Pesquisas em Biologia Aquática (CPBA), Instituto Nacional de pesquisas da Amazônia (INPA). Avenida André Araújo n 2936, Aleixo, CEP 69060-001, Manaus, AM, Brazil. Tel: +55 92 3643-3381; Fax: +55 92 3643-3249.

${ }^{2}$ Laboratório de Bioquímica e Biologia Molecular (LBBM), Centro de Ciências Tecnológicas da Terra e do Mar (CTTMar), Universidade do Vale do Itajaí (UNIVALI). Rua Uruguai n 458, Centro, CEP 88302-202, Itajaí, SC, Brazil. Tel: +55 47 3341-7716 Ext. 7716.
\end{abstract}

(Received April 26, 2010; Accept June 06, 2011)

\begin{abstract}
In this study we address the genotoxicity and putative mutagenic effects of benzene (BZN) in the erythrocytes of the electric fish Apteronotus bonapartii (Gymnotiformes, Apteronotidae) using the micronucleus test (MN) and comet assay, under controlled laboratory conditions. Electric fish were collected in the Solimões River, Manaus-AM, Brazil, and the specimens were exposed to 10 and 25 ppm concentrations of BZN, in 150L tanks. Blood samples were collected at $0\left(\mathrm{~T}_{0}\right), 24,48,72$ and 96 hours of exposure. For the concentration of $10 \mathrm{ppm}$ BZN, the number of comets was significantly higher than $\mathrm{T}_{0}$ levels after exposure of 48 hours, whereas the nuclear abnormalities (including $\mathrm{MN}$ ) did not show any increase in relation to the controls $\left(\mathrm{T}_{0}\right)$ up to 96 hours. For the $25 \mathrm{ppm}$ BZN, MN rates presented a significant increase after 72 hours, whereas other types of nuclear abnormalities increased in frequency after various exposure times, ranging from 24 to 72 hours. The number of comets increased significantly from 24 hours onwards for $25 \mathrm{ppm}$ BZN. Both assays also showed a gradual increase in the number of damaged cells after longer exposure periods, indicating a time-dependent effect, especially at the highest BZN concentrations tested. This investigation reinforces the potential use of the endemic South American electric fish as a suitable genotoxicity biological model for biomonitoring purposes in the Amazon.
\end{abstract}

Keywords: Comet assay, Micronucleus test, Apteronotus bonapartii, Benzene, Biomonitoring, Electric fish, Amazon

Teste de Micronúcleo e Ensaio Cometa em eritrócitos

do peixe elétrico amazônico Apteronotus bonapartii exposto ao benzeno

\section{Resumo}

Neste estudo nós abordamos a genotoxicidade e os efeitos potencialmente mutagênicos do benzeno (BZN) nos eritrócitos do peixe elétrico Apteronotus bonapartii (Gymnotiformes, Apteronotidae) usando o teste de micronúcleo (MN) e o ensaio cometa, em laboratório, sob condições controladas. Peixes elétricos foram coletados no rio Solimões, Manaus-AM, Brasil, e os espécimes foram expostos a concentrações de 10 e $25 \mathrm{ppm}$, em tanques de $150 \mathrm{~L}$. Amostras de sangue foram coletadas no tempo 0 (T0) e após 24, 48, 72 e 96 horas de exposição. Para a concentração de 10 ppm de BZN, o número de cometas foi significativamente maior que os níveis de T0 após 48 horas de exposição, enquanto as anormalidades nucleares (incluindo MN) não mostraram nenhum incremento em relação ao controle (T0) mesmo após 96 horas. Para a concentração de 25ppm de BZN, os valores de MN apresentaram incremento significativo depois de 72 horas, enquanto os outros tipos de anormalidades nucleares aumentaram em frequência após tempos variados de exposição, variando entre 24 e 72 horas. O número de cometas aumentou significativamente a partir de 24 horas para $25 \mathrm{ppm}$ de BZN. Os dois ensaios também mostraram um aumento gradual no número de células danificadas para períodos de exposição maiores, indicando um efeito tempo-dependente, especialmente na concentrações mais alta de BZN testada. Esta investigação reforça o potencial de uso dos peixes elétricos, endêmicos da América do Sul, como um modelo biológico plausível para testes de genotoxicidade, em questões de biomonitoramento na Amazônia.

Palavras chaves: Ensaio Cometa, Teste de Micronúcleo, Apteronotus bonapartii, Benzeno, Biomonitoramento, Peixes

*Corresponding author: José A. Alves-Gomes, e-mail: puraque@inpa.gov.br 


\section{INTRODUCTION}

Benzene $\left(\mathrm{BZN}, \mathrm{C}_{6} \mathrm{H}_{6}\right)$ is a volatile, monoaromatic hydrocarbon component of crude petroleum, which has been extensively used since the late $19^{\text {th }}$ Century in several industrial processes, especially as a solvent or as a starting material for the synthesis of other chemicals or compounds, such as styrene (vinyl benzene), phenol, epoxy and phenolic resins, nylon and other products like pesticides, rubbers, explosives and dyes (ATSDR 2000).

Together with toluene, ethylbenzene plus the ortho-, metaand para-xylene, benzene forms what is known as "BTEX compounds", BTEX constitutes the petroleum fraction with the highest water solubility, therefore, after oil spills, these compounds are the most likely to reach water reservoirs and cause various types of damage to the organisms present in the aquatic habitats. Several studies using single-cell gel assay have shown that BZN can effectively induce micronuclei and other types of DNA damage, in fish and other vertebrate cells (Diaz et al., 1980; Misra et al., 1987; Harper et al., 1989; Andreoli et al., 1997; Whysner et al., 2004; Maffei et al., 2005; Wetmore et al., 2008). Benzene can also induce structural and numerical chromosome aberrations, sister chromatid exchanges and micronuclei by various routes of exposure (WHO, 1993).

In the Brazilian Amazon, petroleum and its derivatives are among the main environmental concerns. This is a consequence of the growing regional production (and associated risks of spills in every step of the productive process, from exploration to commercialization), and also due to pollution from boats, these being the main form of transport in the North region of Brazil. Every day, an uncalculated amount of petroleumderived chemicals, especially fuel (gasoline, kerosene and diesel), leaks into all types of aquatic habitats in the region. Furthermore, aquatic habitats are particularly sensitive because a wide variety of pollutants derived from human activities sooner or later end up being washed to streams and rivers, where they can act synergistically, jeopardizing the quality of these habitats, especially around urban areas (Giulio \& Hinton, 2008).

The use of biological models for the biomonitoring of aquatic habitats is becoming increasingly relevant in several areas of the globe. In this regard, the South American electric fish (order Gymnotiformes) can be considered a differentiated model organism because, among other peculiarities, they possess an active electric sense, i.e. they generate and detect electrical gradients in the water, and use this system for electrolocalization and communication (review in Bullock \& Heiligenberg, 1986). The performance of this complex motorsensory system is closely linked to the physical and chemical properties of the water that the fish inhabits, and changes in water chemistry can induce changes in the pattern of electric organ discharges (EOD) of the fish. These fish have therefore been tested by a real-time biomonitoring system (Pimentel-Souza \& Siqueira, 1992; Thomas et al., 1996; Alves-Gomes et al., 2004). Among the gymnotiforms, the fish of the Family Apteronotidae are of special interest, because the temporal pattern of their electric organ firing rate is the most stable biological oscillator known (Moortgat et al., 2000). Physiological alterations in the internal sate of the fish, caused by pollutants in the water could, therefore, be more easily detected as variations in the otherwise very stable EOD firing pattern. Therefore, apteronotids are strong candidates, among the gymnotiforms, for use as central element of a real-time biomonitoring system (Thomas et al., 1996; Alves-Gomes et al., 2004).

Also, to complement other ongoing studies on the performance of electric fish as a potential biomonitoring model organism, in this study we used the micronucleus test (MN) and the alkaline comet assay to investigate the effects of benzene exposure under controlled laboratory conditions, on the erythrocytes of the apteronotid electric fish Apteronotus bonapartii.

\section{MATERIAL AND METHODS}

\section{Chemicals}

We used pure, analytical benzene (MERCK, CAS No. 7143-2) at concentrations of $10 \mathrm{ppm}\left(1.5 \mathrm{~mL}^{\left.150 \mathrm{~L}^{-1}\right) \text { and } 25}\right.$

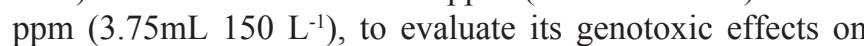
the erythrocytes of electric fish. BZN was first dissolved in five liters of water taken from the experimental tank, then this concentrated benzene solution was mixed with the remaining water $(145 \mathrm{~L})$ in the tanks, which already contained the electric fish. The time the chemical was introduced to the experimental tanks was defined as Time Zero, or $\mathrm{T}_{0}$.

\section{Fish collection and experimental treatments}

Electric fish of the species Apteronotus bonapartii (Gymnotiformes: Apteronotidae), were collected in two areas close to Manaus-AM, Brazil (Fig. 1), in the Solimões River: near Xiborena Island ( $3^{\circ} 07^{\prime} 30^{\prime \prime} \mathrm{S}$ and $59^{\circ} 52^{\prime} 25^{\prime \prime} \mathrm{W}$ ) and Marchantaria Island $\left(03^{\circ} 14^{\prime} 30^{\prime \prime} \mathrm{S}\right.$ and $\left.059^{\circ} 56^{\prime} 20^{\prime \prime} \mathrm{W}\right)$, by means of seine nets in the shallow, grassy marginal waters. The fish were transported in $20-30 \mathrm{~L}$ plastic bags filled with about 8-12 L of water, from the collection site to a holding facility at the Laboratório de Fisiologia Comportamental e Evolução (LFCE) of the Instituto Nacional de Pesquisas da Amazônia (INPA), Manaus. At the LFCE we used a $500 \mathrm{~L}$ tank filled up to the $150 \mathrm{~L}$ mark to hold the fish prior to the benzene treatments. A second tank, the experimental tank, was used for both benzene treatments, carried out in two different time periods. Both the holding and the experimental tanks were initially filled with water from an artesian well that supplies the laboratory. The well water was left to mature in the tanks for at least one week prior to use, using a biological filter and an aerator. The physical and chemical parameters of the tank water, when the fish were placed in it, are shown in Table 1, in comparison with the water of the Solimões river.

Our experimental design consisted of a total of sixteen $A$. bonapartii (averaging $14.3 \pm 5 \mathrm{~g}$ in weight and $15 \pm 2 \mathrm{~cm}$ in length), divided into two groups of eight. One group was 
Table 1 - Physical and chemical properties of the water in the experimental tanks and from the Solimões River.

\begin{tabular}{lcc}
\hline Measured parameter & Artesian water & Solimões river \\
\hline $\mathrm{T}\left({ }^{\circ} \mathrm{C}\right)$ & 28.6 & 25.8 \\
$\mathrm{pH}$ & 4.37 & 5.69 \\
Conductivity $(\mu \mathrm{S} / \mathrm{cm})$ & 11 & 94 \\
Chemical oxygen demand $\left(\mathrm{mg} \mathrm{O}_{2} / \mathrm{L}\right)$ & 4.8 & 5.66 \\
$\mathrm{O}_{2}(\%$ saturation $)$ & $63.10 \%$ & $70.80 \%$ \\
Total solids $(\mathrm{g} / \mathrm{L})$ & 0.006 & 0.06 \\
\hline
\end{tabular}

exposed to $10 \mathrm{ppm}$ of benzene, and the second was exposed to a 25 ppm BZN dosage. These concentrations were defined in a previous work, which used $10 \mathrm{ppm}$ benzene as positive control for micronucleus induction (Al-Sabti, 2000), and also to be comparable to a previous paper with a second species of electric fish (Bücker et al. 2006), previously published. Our control levels, or the basal damage in the DNA, were established as the counts of both assays (MN and comet assay) at time zero ( $\left.\mathrm{T}_{0}\right)$, as in Buschini et al. (2004), immediately before the addition of BZN to the experimental tanks. This control also enabled us to establish the basal counts for the fish under conditions of captivity. Prior to releasing the contaminant in the tank, the fish were acclimatized for 1 week in the holding tank and then transferred to the experimental tank.

The two groups of fish used were collected in two separate field trips to nearby collection sites. Except for the second fish collection event, both experiments followed the same procedures of fish handling and tank maintenance, in accordance with the general guidelines of the CEUA (Committee of Ethics in the Use of Animals) of the INPA.

The experimental tanks were located in an outdoor area, covered with a lid to prevent the entry of rain water, and the fish were fed once a day on either earthworms or beetle larvae, bred at the LFCE/INPA. The light cycle followed the natural light conditions of the tropics, with a 12:12 hour light:dark cycle. The water temperature was around $26 \pm 2{ }^{\circ} \mathrm{C}$ throughout the experiment.

Blood was collected from the caudal vein of all the fish immediately beforehand $\left(\mathrm{T}_{0}\right)$, in order to obtain basal DNA

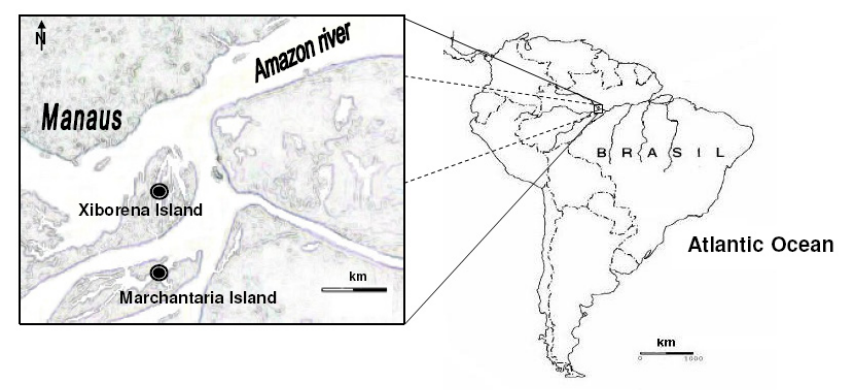

Figure 1 - Sampling sites of the fish used in the present study. Xiborena Island ( $3^{\circ} 07^{\prime} 30^{\prime \prime} \mathrm{S}$ and $\left.59^{\circ} 52^{\prime} 25^{\prime \prime} \mathrm{W}\right)$ and Marchantaria Island $\left(03^{\circ} 14^{\prime} 30^{\prime \prime} \mathrm{S}\right.$ and $\left.059^{\circ} 56^{\prime} 20^{\prime \prime} \mathrm{W}\right)$ damage levels (Gontijo et al. 2003), and at 24, 48, 72 and 96 hours after each treatment started, without the addition of new fish. The same blood collected was used for both the $\mathrm{MN}$ and the Comet assay tests. For each test, one slide was mounted per fish for each exposure time. Differences in the " $N$ " in Tables I and II are due to either fish loss or differences in the number of slides counted (see text below).

\section{Micronucleus test and nuclear abnormalities}

The MN test was performed according to the methods of Grisolia \& Cordeiro (2000) with some minor modifications. Briefly, blood samples obtained from a puncture to the caudal vein using heparinised syringes at $0\left(\mathrm{~T}_{0}\right), 24,48,72$ and 96 hours of exposure to benzene were immediately smeared onto clean glass slides, air dried overnight, and then fixed in absolute methanol for $15 \mathrm{~min}$. Each slide was stained with 5\% Giemsa solution for $20 \mathrm{~min}$. At least 1,000 erythrocytes for each $A$. bonapartii specimen were identified, counted and scored microscopically under $1,000 \mathrm{X}$ in an Axiophot 2 Carl Zeiss microscope, located at INPA's thematic electron microscopy laboratory. The main criteria for scoring the micronucleus (MN) were based on those of Al-Sabti \& Matcalfe (1995), considering the absence of connections with the main nucleus, similar coloration, and a size of between $1 / 10$ to $1 / 30$ of the size of the main nucleus, since most fish chromosomes are much smaller than mammalian chromosomes, as pointed out by Schmidt (1975). The nuclear abnormalities observed were classified into five categories, adapting the classification proposed by Ayllon \& Garcia-Vazquez (2000): a) Micronuclei; b) Binucleated nucleus: two completely separated nuclei in the same erythrocyte's cytoplasm; c) Lobed nucleus: evaginations of the nuclear envelope of different sizes; d) Notched nucleus: presents an noticeable depression into the nucleus that does not contain nuclear material; and e) Other Nuclear Abnormalities: all the other types of nuclear morphological alterations found in the nuclei that could not be fitted under the previous categories. For the statistical analysis we used the non-parametric Mann-Whitney $U$ test $(p<0.05)$ to compare the effects of different treatments and exposure times in relation to $\mathrm{T}_{0}$. The frequencies of micronuclei and other nuclear damages were calculated for each individual/ slide of $A$. bonapartii and expressed as per 1,000 cells (\%o).

\section{Comet assay}

The alkaline comet assay was performed according to published methods (Lemos et al., 2005; Hartmann et al., 2004), adapted with minor modifications to the specific conditions associated the species $A$. bonapartii. A $10 \mu \mathrm{L}$ subaliquot was taken from each diluted blood sample and mixed with $75 \mu \mathrm{L}$ low melting point (LMP) agarose $(0.5 \%)$. The suspension was spread onto slides previously coated with normal melting point agarose (1.5\%), prepared in phosphatebuffered saline (PBS). The slides were cover slipped and the agarose solidified at $4^{\circ} \mathrm{C}$ for $20 \mathrm{~min}$. A second layer of LMP agarose was then added $(75 \mu \mathrm{L})$. After brief agarose 
solidification on ice, the cover slip was carefully removed and the slides were immersed in lysis solution $(2.5 \mathrm{M} \mathrm{NaCl}, 100$

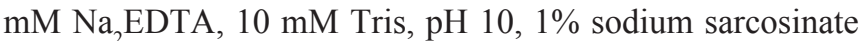
with $1 \%$ Triton $\mathrm{X}-100$, and $10 \%$ DMSO was added just before use) for at least 1 hour, at $4^{\circ} \mathrm{C}$. Afterwards, the slides were washed in ice-cold PBS in order to remove excess salt and detergents, placed in electrophoresis buffer $(0.3 \mathrm{mM} \mathrm{NaOH}$, 1 mM EDTA, $\mathrm{pH}>13$ ) for DNA unwinding for 10 minutes, and then electrophoresed in the same buffer at $25 \mathrm{~V}$ and 300 $\mathrm{mA}\left(0.8 \mathrm{~V} \mathrm{~cm}^{-1}\right)$ for 5 minutes. These procedures and times were adapted from the protocol proposed by Gontijo et al. (2003), after we tested different times for unwinding and electrophoresis. The times that provided the best results for the fish used in this study were ten minutes for unwinding, and five minutes for electrophoresis.

The slides were neutralized in $400 \mathrm{mM}$ Tris- $\mathrm{HCl}(\mathrm{pH} 7.5)$ for $10 \mathrm{~min}$, fixed in absolute ethanol for $5 \mathrm{~min}$, and stored in the dark until analysis. Observations were made using an Axiophot 2 Carl Zeiss fluorescent microscope. The slides were dyed with acridine orange $(3 \mu \mathrm{g} / \mathrm{mL})$ immediately before examination. A total of 100 comets for each slide were scored for each individual fish. Mann-Whitney $U$ tests were used for comparisons between the exposure times and $\mathrm{T}_{0}$, and a $\mathrm{p}$-value of 0.05 or less was considered statistically significant.

For the comet assay evaluation, all the slides were independently coded and scored by a single observer. Under a fluorescence microscope (magnification of $400 \mathrm{X}$ ), first a squared perimeter was delimited in a random location within the field of vision of the slide, and within each square, one hundred cells were analyzed/counted for each animal. The patterns of DNA migration, determined visually (Matsumoto et al., 2006; Villela et al., 2006), were used to categorize four different damage classes in the cells, as follows: class 0 (no damage), class 1 (little damage), class 2 (medium damage) and class 3 (extensive damage). A damage index (DI) was calculated by multiplying the number of nuclei found in a class, multiplied by the class number. Therefore, the DI could range from 0 (100 cells with class 0 damage) to 300 (100 cells with class 3 damage) (Matsumoto et al., 2006). Mann-Whitney $U$ tests were used for the comparisons between the exposure times and $\mathrm{T}_{0}$, and a p-value of 0.05 or less was considered statistically significant.

\section{RESULTS}

\section{Fish losses}

For the treatment with $10 \mathrm{ppm}$ benzene, one fish died between 24 and 48 hours and a second died in the third day of exposure. For $25 \mathrm{ppm}$ of BZN, the only loss was a single fish, which died within the first 24 hours. Due to these losses, and because it was not possible to obtain at least one readable slide for each individual for the different treatments at every blood collection, our " $N$ ", in Tables 2 and 3 , represent the total number of slides processed for each time of exposure.

\section{Micronucleus and other nuclear abnormalities}

Table 2 shows the results of the MN and the other types of nuclear abnormalities found. A total of 67,000 erythrocytes from the specimens used were analyzed for the laboratory assays. The MN and other types of nuclear abnormalities were quantified by comparing the respective frequencies found for the different exposure times with the frequencies obtained at time zero $\left(T_{0}\right)$.

Comparing the $\mathrm{MN}$ numbers with $\mathrm{T}_{0}$, no significant increase in $\mathrm{MN}$ was found for the concentration of $10 \mathrm{ppm}$ BZN during the time of our experiment; for $25 \mathrm{ppm}$, significant MN inductions were detected at 72 and 96 hours.

For the remaining types of nuclear deformities (Table 2 ), at the concentration $10 \mathrm{ppm}$, we only found a significant

Table 2 - Mean number of abnormalities per 1,000 erythrocytes and respective standard deviation for the different types of nuclear abnormalities considered. $N=$ number of slides ( 1,000 cells per slide) analyzed for each exposure time.

\begin{tabular}{|c|c|c|c|c|c|c|c|}
\hline Treatment & $N$ & $\begin{array}{c}\text { Exposure } \\
\text { Time }\end{array}$ & MN & Binucleated & Lobed & Notched & $\begin{array}{l}\text { Other nuclear } \\
\text { abnormalities }{ }^{1}\end{array}$ \\
\hline & 8 & $T_{0}$ & $0.13( \pm 0.35)$ & $0.63( \pm 0.74)$ & $2.00 \quad( \pm 2.07)$ & $0.63( \pm 0.74)$ & $5.88 \quad( \pm 4.45)$ \\
\hline Benzene & 7 & $24 h$ & $1.14( \pm 2.19)$ & $2.71( \pm 5.88)$ & $5.43 \quad( \pm 9.18)$ & $1.29( \pm 1.60)$ & $11.29( \pm 15.93)$ \\
\hline \multirow[t]{3}{*}{ (10 ppm) } & 7 & $48 h$ & $1.00( \pm 1.41)$ & $1.29( \pm 1.70)$ & $1.86 \quad( \pm 1.68)$ & $0.71( \pm 1.11)$ & $4.29 \quad( \pm 3.25)$ \\
\hline & 6 & $72 \mathrm{~h}$ & $3.17( \pm 5.15)$ & $2.50( \pm 4.28)$ & $7.33( \pm 11.64)$ & $1.83( \pm 3.54)$ & $27.67( \pm 33.12)$ \\
\hline & 6 & $96 \mathrm{~h}$ & $0.50( \pm 0.84)$ & $2.17( \pm 3.49)$ & $12.67( \pm 8.80)$ & $1.17( \pm 1.17)$ & $32.33( \pm 28.33)^{*}$ \\
\hline Treatment & $N$ & $\begin{array}{c}\text { Exposure } \\
\text { Time }\end{array}$ & $\mathrm{MN}$ & Binucleated & Lobed & Notched & $\begin{array}{l}\text { Other nuclear } \\
\text { abnormalities }\end{array}$ \\
\hline & 7 & $T_{0}$ & $0.14( \pm 0.38)$ & $0.14( \pm 0.38)$ & $1.57( \pm 2.70)$ & $0.14( \pm 0.38)$ & $0.86 \quad( \pm 1.21)$ \\
\hline Benzene & 7 & $24 \mathrm{~h}$ & $1.29( \pm 2.56)$ & $1.14( \pm 0.90)^{*}$ & $2.00( \pm 1.63)$ & $0.43( \pm 0.79)$ & $10.43( \pm 3.31)^{*}$ \\
\hline \multirow[t]{3}{*}{ (25 ppm) } & 7 & $48 \mathrm{~h}$ & $0.14( \pm 0.38)$ & $0.86( \pm 0.90)$ & $2.71( \pm 1.38)^{*}$ & $0.86( \pm 0.69)$ & $12.29( \pm 2.43)^{*}$ \\
\hline & 7 & $72 \mathrm{~h}$ & $2.00( \pm 1.15)^{*}$ & $1.29( \pm 1.38)$ & $7.71( \pm 6.13)^{*}$ & $1.57( \pm 1.51)^{*}$ & $49.43( \pm 21.19)^{*}$ \\
\hline & 5 & $96 h$ & $4.00( \pm 2.00)^{*}$ & $0.20( \pm 0.45)$ & $11.60( \pm 0.89)^{*}$ & $2.40( \pm 0.55)^{* *}$ & $53.20( \pm 10.52)^{*}$ \\
\hline
\end{tabular}

* indicates significant results $(\mathrm{p}<0.05)$ in relation to time zero $\left(\mathrm{T}_{0}\right)$ for the non-parametric Mann-Whitney $U$ test. ${ }^{1}$ Other nuclear abnormalities are all the other types of nuclear morphological alterations found in the nuclei that could not be fitted into the previous categories. 
increment $(p<0.05)$ in the in the number of "Other nuclear abnormalities" at 96 hours. None of the values found for the remaining classes of nuclear abnormalities were statistically different from $\mathrm{T}_{0}$ for this concentration. At the benzene concentration of $25 \mathrm{ppm}$, we found an increase of MN after 72 hours of exposure, as mentioned above; "Lobed" after $48 \mathrm{~h}$, "Notched" after $72 \mathrm{~h}$, and "Other nuclear abnormalities" after $24 \mathrm{~h}$. There was a transient increase in the number of "Binucleated" cells after $24 \mathrm{~h}$, which disappeared as the experiment progressed.

\section{Comet assay}

For the Comet assay, the fish exposed to both concentrations of BZN suffered significant erythrocyte nuclear damage within a shorter time period than when damage was estimated by MN alone. When compared with the negative control counts, at $\mathrm{T}_{0}$ the DI was significantly higher in the fish exposed to 10 PPM BZN at $48 \mathrm{~h}$, and remained higher $72 \mathrm{~h}$ and $96 \mathrm{~h}$ after treatment $(p<0.05)$. At the higher dosage, fish treated with 25 PPM BZN, the Comet assay indicated damage after $24 \mathrm{~h}$ of exposure and this trend continued up to the last sample at 96h, when the values were compared to the baseline values $\left(\mathrm{T}_{0}\right)$.

\section{DISCUSSION}

We evaluated the genotoxicity of benzene on erythrocytes in $A$. bonapartii using two complementary tests: the Micronucleus test and the Comet assay. Our main goals were to evaluate the suitability of these two protocols, using an apteronotid gymnotiform fish as the model organism, and to expand our understanding of the potential use of this group of fish as biomonitors.

Bücker et al. (2006) were the first to publish the results of genotoxic studies with electric fish (genus Eigenmannia), and this is the first study to use an apteronotid genus. These aspects are especially relevant because they complement other studies well, showing that electric fish have good potential for use as a model for biomonitoring environmental pollution in aquatic ecosystems, and are especially suited to real-time monitoring (Pimentel-Souza \& Siqueira, 1992; Thomas et al. 1996; Alves-Gomes et al. 2004).

In general terms, our results allowed us to establish, based upon statistical analysis, and for the doses considered, that the comet assay detects DNA damage caused by BZN within a shorter period of time than MN. Comets were statistically more frequent in the treatment fish at lower doses of BZN and at earlier exposure times than MN. The data also support the idea that the increase in comet frequency of $A$. bonapartii is time- and dose-dependent. However, because each test reflects different types of damage to the DNA, specific considerations need to be taken into account when evaluating the performances of these two tests. For instance, the MN is associated with the cell cycle and measures persistent DNA damage that cannot be repaired, including small subsets of unrepaired double-strand breaks, breaks at the level of chromatids and non-repairable aneugenic effects or DNA lesions, after their fixation into chromosome mutations.

The $10 \mathrm{ppm}$ BZN treatment induced no significant increase in $\mathrm{MN}$ for the time tested. For this concentration, the only nuclear abnormality that showed a consistent and significant increase in frequency was the damage classified under "Other nuclear abnormalities" at 96 hours of exposure. The relatively low levels of MN detected for this concentration could be related to two main possibilities, which are not mutually exclusive: 1) Because the DNA/nuclear abnormalities targeted under the $\mathrm{MN}$ test require cell division, there must be a time lag between the time of first exposure and the time of MN appearance; and 2) 10 ppm BZN alone was not a sufficiently high dose to induce $\mathrm{MN}$ in the species studied, due to the internal physiological and biochemical characteristics of the species studied.

Table 3 - Mean number of damaged cells (in \%) within each respective class, damage index and respective standard deviations (SD) for the comet assay. $N=$ number of slides (100 cells per slide) analyzed for each exposure time.

\begin{tabular}{|c|c|c|c|c|c|c|c|c|}
\hline \multirow{2}{*}{ Treatment } & \multirow{2}{*}{$N$} & \multirow{2}{*}{$\begin{array}{c}\text { Exposure } \\
\text { Times }\end{array}$} & \multicolumn{5}{|c|}{ Mean number of cells in each class of damage ( \pm SD) } & \multirow{2}{*}{ Damage Index } \\
\hline & & & & $\mathbf{I}$ & II & III & IV & \\
\hline \multirow{5}{*}{$\begin{array}{l}\text { Benzene } \\
\text { (10 ppm) }\end{array}$} & 8 & $\mathbf{T}_{0}$ & 29.9 & $( \pm 15.9)$ & $47.4( \pm 10.2)$ & $17.6( \pm 6.1)$ & $5.1( \pm 3.3)$ & $97.9( \pm 24.7)$ \\
\hline & 8 & $24 \mathrm{~h}$ & 29.0 & $( \pm 6.2)$ & $40.0 \quad( \pm 6.8)$ & $21.0 \quad( \pm 8.0)$ & $10.0 \quad( \pm 3.4)$ & $112.0( \pm 20.0)$ \\
\hline & 7 & $48 \mathrm{~h}$ & 8.0 & $( \pm 6.7)$ & $43.3( \pm 11.8)$ & $33.7( \pm 10.7)$ & $15.0 \quad( \pm 5.9)$ & $155.7( \pm 25.8)^{*}$ \\
\hline & 6 & $72 \mathrm{~h}$ & 2.5 & $( \pm 3.4)$ & $29.0( \pm 11.2)$ & $37.3( \pm 12.6)$ & $32.2( \pm 10.6)$ & $200.2( \pm 68.1)^{*}$ \\
\hline & 6 & $96 \mathrm{~h}$ & 4.2 & $( \pm 3.4)$ & $20.7( \pm 7.0)$ & $31.8 \quad( \pm 8.7)$ & $43.3( \pm 14.5)$ & $214.3( \pm 57.5)^{*}$ \\
\hline \multirow{2}{*}{ Treatment } & \multirow{2}{*}{$N$} & \multirow{2}{*}{$\begin{array}{c}\text { Exposure } \\
\text { Times }\end{array}$} & \multicolumn{5}{|c|}{ Mean number of cells in each class of damage ( \pm SD) } & \multirow{2}{*}{ Damage Index } \\
\hline & & & & $\mathbf{I}$ & II & III & IV & \\
\hline \multirow{5}{*}{$\begin{array}{l}\text { Benzene } \\
\text { (25 ppm) }\end{array}$} & 8 & $\mathbf{T}_{0}$ & 26.8 & $( \pm 10.2)$ & $42.0( \pm 11.1)$ & $23.6( \pm 8.1)$ & $7.6( \pm 3.8)$ & $112.0( \pm 17.3)$ \\
\hline & 7 & $24 \mathrm{~h}$ & 3.1 & $( \pm 3.5)$ & $38.3( \pm 8.7)$ & $40.5( \pm 3.0)$ & $18.1( \pm 7.8)$ & $173.6( \pm 14.7)^{*}$ \\
\hline & 7 & $48 \mathrm{~h}$ & 10.9 & $( \pm 5.8)$ & $33.4( \pm 9.6)$ & $32.6( \pm 9.5)$ & $23.1( \pm 6.1)$ & $167.9( \pm 19.7)^{*}$ \\
\hline & 7 & $72 \mathrm{~h}$ & 6.0 & $( \pm 5.1)$ & $28.0( \pm 11.5)$ & $34.3( \pm 5.9)$ & $31.7( \pm 10.6)$ & $191.7( \pm 29.3)^{*}$ \\
\hline & 7 & $96 \mathrm{~h}$ & 5.6 & $( \pm 3.7)$ & $19.3 \quad( \pm 6.2)$ & $36.1( \pm 5.4)$ & $39.0 \quad( \pm 5.3)$ & $208.5( \pm 13.7)^{*}$ \\
\hline
\end{tabular}

* indicates significant results $(\mathrm{p}<0.05)$ in relation to time zero $\left(\mathrm{T}_{0}\right)$ for the non-parametric Mann-Whitney $U$ test. 
Al-Sabti (2000) used a concentration of $10 \mathrm{ppm}$ of BZN in carp Carassius auratus as positive control and counted MN after exposure times of 3, 6 and 9 days. Comparing the same exposure time for the two species used in each respective study (72 hours) for $10 \mathrm{ppm}$ BZN, we found an average of 3.1 MN.1,000 erythrocytes ${ }^{-1}$ for our fish, whereas Al-Sabti (2000) report a figure of 8.36 MN.1,000 cells ${ }^{-1}$. Furthermore, our negative control figure is $0.14 \mathrm{MN} \cdot 1,000^{-1}$, whereas that obtained by Al-Sabti (2000) is 4.7 MN.1,000 cells ${ }^{-1}$. Proportionally, the increase in the number of MN was much higher in our case, but the high level of MN in the negative control found by Al-Sabti (2000) is, at the very least, curious. The discrepancies between our results and those of Al-Sabti may be related to several factors, including inter-specific differences in the physiology of the species, their differential resistance to the contaminant, or even differential conditions associated with methodological procedures used, such as handling and captivity conditions.

For 25 ppm BZN, our results show that MN becomes more frequent only after 72 hours of exposure, coinciding with the higher levels of nuclear abnormalities in the erythrocytes (Table 2). Previous studies, using doses compatibles to those used here, report the induction of micronuclei by benzene in human lymphocytes (Andreoli et al., 1997), in rodents (Whysner et al., 2004) and fish (Al-Sabti, 2000). However, similar to the results and trends found for $10 \mathrm{ppm}$ BZN, the nuclear damage classified in the group "Other nuclear abnormalities" was the first type of damage to be significantly increased, after 24 hours of exposure time. Also, if we consider that "Lobed", "Notched" and even "Binucleated" types of nuclear abnormalities were also induced before $\mathrm{MN}$ (see Table 2), our results reinforce the idea that $\mathrm{MN}$ counts alone should be interpreted cautiously, and should be used primarily to complement other genotoxicity assays. A study by Ayllon \& Garcia-Vasquez (2000) also found inductions of other nuclear abnormalities, even in the absence of micronuclei. As a consequence, they suggest the inclusion of these "other nuclear abnormalities" in fish genotoxicity analyses based on micronuclei counts.

Micronucleated erythrocytes require a passage through the mitosis to be recognizable, a process which in most species, takes place after 2 or 3 days (Hartmann et al., 2001; Udroiu, 2006). Likewise, Al-Sabti \& Metcalfe (1995) demonstrated that the maximal micronucleus induction occurred from 1 to 5 days post-exposure. It is known that the mitotic rate of fish erythrocytes is low (Grisolia \& Cordeiro, 2000), therefore, this may be one of the reasons for the low frequencies of micronuclei in our $10 \mathrm{ppm}$ dosage. We hypothesize that the MN counts would have been much more prominent in our study if we had continued our blood sample analyses for a longer period, i.e. MN could still be considered an appropriate assay for larger concentrations and longer exposition times, as demonstrated in other studies (Al-Sabti \& Metcalfe 1995; Al-Sabti 2000).

For $25 \mathrm{ppm}$ BZN we also observed a significant increase in the number of "Lobed" cells after 48 hours and of
"Notched" cells after 72 hours. The presence of variations in nuclear morphology of fish erythrocytes has been previously described in several studies, and in several cases, they have been interpreted as nuclear lesions analogous to micronuclei (Sanchez-Galán et al., 1998; Ayllon \& Garcia-Vasquez, 2000; Çavas \& Ergene-Gözükara, 2005). Binucleated and budding cell nuclei are types of nuclear abnormalities that can also be considered indicative of genotoxic elements in the environment (Ayllon \& Garcia-Vasquez, 2000; Serrano-Garcia \& Montero-Montoya, 2001). Erythrocytes of fish in polluted waters often show micronuclei, but binucleated cells can be more common (Wirzinger et al., 2007). Sanchez-Galán et al. (1998), studying brown trout, report that binucleated cells are induced by unspecific pollution along with micronuclei. We found no definite increase in binucleated cells in our assays, except for a transient increase at 24 hour for $25 \mathrm{ppm}$ BZN.

Çavas \& Ergene-Gözükara (2005) used the cichlid Oreochromis niloticus to test the induction of MN by effluents from an oil refinery. Although we cannot establish the proportion of BZN in the effluents, it is worth noting that the author only found $\mathrm{MN}$ in the erythrocytes at a concentration of $20 \% \mathrm{v} / \mathrm{v}$, after 3 days of exposure. At the concentration of $10 \% \mathrm{v} / \mathrm{v}$, the MN counts were only significantly higher after 9 days of exposure. Our results reinforce this trend. In short, considering that for low doses of pollutant a significant increase in $\mathrm{MN}$ counts may require several days to be detected, its use as a marker in fish needs to be considered carefully, especially if the objective is to detect pollutants within a short period of time, as in cases of accidents or spillages of toxic substances in aquatic habitats. Belpaeme et al. (1996) considered the use of MN highly questionable as a laboratory or field indicator for wild fish exposed to chemical contaminants.

The comet assay has also been widely used to detect DNA damage in cells exposed to various physical or chemical agents in aquatic animals. The alkaline version assay has been used under a variety of conditions, including in vitro, in vivo and in situ (Hartmann et al., 2001, 2004; Lee \& Steinert, 2003; De Andrade et al., 2004; Groff et al., 2010; Kumar et al., 2010). In this study, we standardized the comet assay for whole blood erythrocytes of the electric fish, Apteronotus bonapartii.

For the time and doses used, we found a statistically significant increase in the number of damaged nuclei, by means of the comet assay, for both BZN concentrations: with $10 \mathrm{ppm}$ after 48 hours and with $25 \mathrm{ppm}$ after 24 hours. The damage levels also tended to increase with exposure time for both concentrations. A similar effect was also observed for the other electric fish tested so far, Eigenmannia virescens (Bücker et al., 2006).

These results require further investigation of the interpretation of "sensitivity" and "specificity" between the micronucleus test and the comet assay. For the benzene concentrations of our study, the use of MN as a sole genotoxicity marker could have led to misleading conclusions, particularly when at the benzene concentration of $10 \mathrm{ppm}$. On the other hand, the results of Hartmann et al. (2001) with mammalian cells reinforce the idea that under certain circumstances, 
contrary to our findings, the Comet assay may be less efficient than MN. Discrepancies between the two tests are reported in the literature and may be due to several reasons, including species-specific differences, the nature of both assays, and type of damage they are detecting (Hartmann et al., 2001; Wirzinger et al., 2007).

Belpaeme et al. (1998) point out that the use of MN as a reliable monitoring tool has not been conclusively proven, and that on the other hand, the simplicity and sensitivity of the comet assay make it an adequate test system for biomonitoring for chronic as well as low level exposure. Moreover, the comet assay under $\mathrm{pH}>13$ is capable of detecting DNA double- strand breaks (DSB) and single-strand breaks (SSB), alkali-labile sites (ALS), DNA-DNA/DNA protein crosslinking, and SSB associated with incomplete excision repair sites (Hartmann et al., 2003).

The literature has established that BZN and its metabolites can induce clastogenic and aneugenic effects in animal cells, generating micronuclei, chromosomal aberrations, sister chromatid exchanges and DNA strand breaks (Whysner et al., 2004). These genotoxic effects could not be detected through $\mathrm{MN}$ alone in $A$. bonapartii at the BZN concentration of $10 \mathrm{ppm}$. However, related effects that caused other nuclear abnormalities were evident after 96 hours of exposure (Table 2). On the other hand, DNA strand breaks that could be associated with the comet assay started within 48 hours (for $10 \mathrm{ppm}$ ) and within 24 hours for $25 \mathrm{ppm}$, in our experiments. These effects persisted until the last sampling time (96 hours). From these results, we suggest that BZN is probably already inducing non-reparable damage in the cells at the concentration of $10 \mathrm{ppm}$, but only mildly, whereas for $25 \mathrm{ppm}$, the genotoxic action of BZN is much more evident due to the significant increase of both comet and MN.

Bücker et al. (2006), studying the genotoxic action of BZN $(50 \mathrm{ppm})$ in a different species of electric fish (Eingenmannia virescens), also used $\mathrm{MN}$ and comet assay and found similar results to those reported here. There was no significant difference in the number of MN induced during the 96 hours of experiment, despite a transient peak in MN levels at 48 hours. The $\mathrm{MN}$ levels returned to the same values found at $\mathrm{T}_{0}$ after 15 days. In the case of comet assay, there was a significant increase in the damage index after 24 hours of exposure. The effects were also time-dependent, since the values increased steadily with exposure time, up to 96 hours. Unlike a study by Bücker et al. (2006) in E. virescens, we did not test the $50 \mathrm{ppm}$ concentration of BZN in A. bonapartii.

\section{CONCLUSIONS}

The comet assay and MN are two types of assays which detect different but complementary types of damage in DNA. In our study, the genotoxic effects of BZN at $10 \mathrm{ppm}$ were typified by an increase in the other types of nuclear abnormalities (but not in MN), after 96 hours of exposure. For the same concentration, the comet assay evidenced the damaging effects of BZN within 48 hours of exposure. As we considered higher concentrations of pollutant ( $25 \mathrm{ppm})$, the anaeugenic and clastogenic effects were detected by $\mathrm{MN}$, which were induced at between 48 and 72 hours and by other types of nuclear aberrations within 24 hours of exposure. Likewise, for $25 \mathrm{ppm}$, the comet assay indicated the presence of a genotoxic agent in the water within 24 hours. Since comets were induced earlier and for lower doses of benzene than $\mathrm{MN}$, the former appears to be more suitable than $\mathrm{MN}$ count for detecting benzene in aquatic environments, especially when rapid detection of the pollutant is required, and when the erythrocytes of $A$. bonapartii are used as the biological model. A combination of the comet assay and MN count in field monitoring, as well as in laboratory studies, is always recommended for genotoxicity testing, especially for assessing both shorter term genotoxic damage and more persistent effects of pollutants.

The regular use of electric fish as a biomonitor has promising potential, but further research is necessary to elucidate more specifically how these fish may react to other types of pollutants, and to other doses of BZN.

Acknowledgements: The authors thank Dr. Juliana da Silva (UFRGS), Dr. Eliana Feldberg (INPA) and MSc. Cristhian Amado Castro Pérez (INPA) for their help with sampling and assistance in the laboratory. Dr. Troy Smith (Indiana University) provided valuable input in the final stages of the manuscript. This work was supported by CNPQ/CT HIDRO Processo 481.691/2004-9, CNPq/CTAMAZÔNIA Process: 553979/2006-0 and grants from the PIPT/FAPEAM Program to José A. Alves Gomes; The Fundação de Amparo à Pesquisa do Estado do Amazonas (FAPEAM) granted a scholarship to Augusto Bücker. We also would like to thank two anonymous reviewers for their critical and helpful comments.

\section{REFERENCES}

AL-SABTI, K., 2000, Chlorotriazine reactive azo red 120 textile dye induces micronuclei in fish. Ecotoxicol. Environ. Saf., 47: 149155. doi:10.1006/eesa.2000.1931.

AL-SABTI, K. \& METCALFE, C.D., 1995, Fish micronuclei for assessing genotoxicity in water. Mutat. Res., 343: 121-135. doi:10.1016/0165-1218(95)90078-0.

ALVES-GOMES, J.A., ROSSONI, D. \& SCHWERTNER, G., 2004, Notas sobre a potencial utilização de peixes elétricos gymnotiformes como bioindicadores na detecção de vazamentos de petróleo. Workshop - Bioindicadores de qualidade de água, Embrapa Meio Ambiente. Jaguareúna, São Paulo.

ANDREOLI, C., LEOPARDI, P. \& CREBELLI, R., 1997, Detection of DNA damage in human lymphocytes by alkaline single cell gel electrophoresis after exposure to benzene or benzene metabolites. Mutat. Res., 377: 95-104. doi:10.1016/S00275107(97)00065-1.

ATSDR, 2000, Agency for Toxic Substances and Disease Registry. Case studies in environmental medicine (CSEM). ATSDR Publication No.: ATSDR-HE-CS-2001-000. Wigington, P. S. \& Harris, B. (Eds.), http://www.atsdr.cdc.gov/csem/benzene/ exposure pathways.html.

AYLLON, F. \& GARCIA-VASQUEZ, E., 2000, Induction of micronuclei and other nuclear abnormalities in European minnow Phoxinus phoxinus and mollie Poecilia latipinna: an 
assessment of the fish micronucleus test. Mutat. Res., 467: 177186. doi:10.1016/S1383-5718(00)00033-4.

BELPAEME, K., COOREMAN, K. \& KIRSCH-VOLDERS, M., 1998, Development and validation of the in vivo alkaline comet assay for detecting genomic damage in marine flatfish. Mutat. Res., 415: 167-184. doi:10.1016/S1383-5718(98)00062-X.

BELPAEME, K., DELBEKE, K., ZHU, L. \& KIRSCH-VOLDERS, M., 1996, Cytogenetic studies of PCB77 on brown trout (Salmo trutta fario) using the micronucleus test and the alkaline comet assay. Mutagenesis, 11: 485-492. doi:10.1093/mutage/11.5.485.

BÜCKER, A., CARVALHO, W. \& ALVES-GOMES, J.A., 2006, Avaliação da mutagênese e genotoxicidade em Eigenmannia virescens (Teleostei: Gymnotiformes) expostos ao benzeno. Acta Amaz., 36: 357-364. doi:10.1590/S0044-59672006000300011.

BUSCHINI, A., MARTINO, A., GUSTAVINO, B., MONFRINOTTI, M., POLI, P., ROSSI, C., SANTORO, M., DÖRR, A.J.M. \& RIZZONI, M., 2004, Comet assay and micronucleus test in circulating erythrocytes of Cyprinus carpio specimens exposed in situ to lake waters treated with disinfectants for potabilization. Mutat. Res. 557: 119-129. doi:10.1016/j.mrgentox.2003.10.008.

BULLOCK, T. \& HEILIGENBERG, W., 1986, Eletroreception. Wiley, New York. 722p.

ÇAVAS, T. \& ERGENE-GÖZÜKARA, S., 2005, Induction of micronuclei and nuclear abnormalities in Oreochromis niloticus following exposure to petroleum refinery and chromium processing plant effluents. Aquatic. Toxicol., 74: 264-71. doi:10.1016/j.aquatox.2005.06.001.

DIAZ, M., REISER, A., BRAIER, L. \& DIEZ, J., 1980, Studies on benzene mutagenesis. Micronucleus test. Experientia, 36: $297-$ 299.

DE ANDRADE, V.M., DE FREITAS, T.R. \& DA SILVA, J., 2004, Comet assay using mullet (Mugil sp.) and sea catfish (Netuma sp.) erythrocytes for the detection of genotoxic pollutants in aquatic environment. Mutat. Res., 560: 57-67. doi:10.1016/j. mrgentox.2004.02.006.

GIULIO,R.T.D.\&HINTON,D.E.,2008, The toxicologyoffishes.CRC Press, Boca Raton.1071p. doi:10.1080/02772240903334930.

GONTIJO, A.M.M.C., BARRETO, R.E., SPEIT, G., REYES, V.A.V., VOLPATO, G.L. \& SALVADORI, D.M.F., 2003, Anesthesia of fish with benzocaine does not interfere with comet assay results. Mutat. Res., 534: 165-172. doi:10.1016/S13835718(02)00276-0.

GRISOLIA, C.K. \& CORDEIRO, C.M.T., 2000, Variability in micronucleus induction with different mutagens applied to several species of fish. Genet. Mol. Biol., 23: 235-239. doi:10.1590/ S1415-47572000000100041.

GROFF, A.A., DA SILVA, J., NUNES, E.A., IANISTCKI, M., GUECHEVA, T.N., DE OLIVEIRA, A.M., DE OLIVEIRA, C.P.F., VAL, A.L. \& HENRIQUES, J.A.P., 2010, UVA/UVBinduced genotoxicity and lesion repair in Colossoma macropomum and Arapaima gigas Amazonian fish. J. Photochem. Photobiol. B, Biol., 99: 93-99. doi:10.1016/j.jphotobiol.2010.02.011.

HARPER, B.L., RAMANUJAM, V.M.S. \& LEGATOR, M.S., 1989, Micronucleus formation by benzene, cyclophosphamide, benzo(a)Pyrene, and benzidine in male, female, pregnant female, and fetal mice. Teratog. Carcinog. Mutagen, 9: 239-252. doi:10.1002/tcm.1770090406.

HARTMANN, A., AGURELl, E., BEEVERS, C., BRENDLERSCHWAAB, C., BURLINSON, B., CLAY, P., COLLINS, A., SMITH, A., SPEIT, G., THYBAUD, G. \& TICE, R.R., 2003, Recommendations for conducting the in vivo alkaline comet assay. Mutagenesis 18: 45-51. doi:10.1093/mutage/18.1.45.

HARTMANN, A., ELHAJOUJI, A., KISKINIS, E., POELLER, F., MARKUS, H. J., FJÄLLMAN, A., FRIEAUFF, W.
\& SUTER, W., 2001, Use of the alkaline comet assay for industrial genotoxicity screening: comparative investigation with the micronucleus test. Food Chem. Toxicol., 39: 843-858. doi:10.1016/S0278-6915(01)00031-X.

HARTMANN, A., SCHUMACHER, M., PLAPPERT-HELBERG, U., LOWE, P., SUTER, W. \& MUELLER, L., 2004, Use of the alkaline in vivo comet assay for mechanistic genotoxicity investigations. Mutagenesis, 19: 51-59. doi:10.1093/mutage/ geg038.

KUMAR, R., NAGPURE, N.S., KUSHWAHA, B., SRIVASTAVA, S.K. \& LAKRA, W.S., 2010, Investigation of the genotoxicity of malathion to freshwater teleost fish Channa punctatus (Bloch) using the micronucleus test and comet assay. Arch. Environm. Contam. Toxicol., 58: 123-130. doi:10.1007/s00244-009-93543.

LEE, R.F. \& STEINERT, S., 2003, Use of the single cell gel electrophoresis/comet assay for detecting DNA damage in aquatic (marine and freshwater) animals. Mutat. Res., 544: 4364. doi:10.1016/S1383-5742(03)00017-6.

LEMOS, N.G., DIAS, A.L., SILVA-SOUZA, A.T. \& MANTOVANI, M.S., 2005, Evaluation of environmental waters using the comet assay in Tilapia rendalli. Environ. Toxicol. Pharmacol., 19: 197-201. doi:10.1016/j.etap.2004.03.011

MAFFEI, F., HRELIA, P., ANGELINI, S., CARBONE, F., FORTI, G.C., BARBIERI, A., SANGUINETTI, G., MATTIOLI, S. \& VIOLANTE, F.S., 2005, Effects of environmental benzene: Micronucleus frequencies and haematological values in traffic police working in an urban area. Mutat. Res., 583: 1-11. doi:10.1016/j.mrgentox.2005.01.011.

MATSUMOTO, S.T., MANTOVANI, M.S., MALAGUTTII, M.I.A., DIAS, A.L., FONSECA, I.C. \& MARIN-MORALES, M.A., 2006, Genotoxicity and mutagenicity of water contaminated with tannery effluents, as evaluated by the micronucleus test and comet assay using the fish Oreochromis niloticus and chromosome aberrations in onion root-tips. Gen. Mol. Biol., 29: 148-158. doi: 10.1590/S1415-47572006000100028.

MISRA, V.,CHAWLA, G.,KUMAR, V.,LAL, H. \& VISWANATHAN, P. N., 1987, Effect of linear alkyl benzene sulfonate in skin of fish fingerlings (Cirrhina mrigala): Observations with scanning electron-microscope. Ecotoxicol. Environ. Saf., 13: 164-168.

MOORTGAT, K.T., BULLOCK, T.H. \& SEJNOWSKI, T.J., 2000, Precision of the pacemaker nucleus in a weakly electric fish: network versus cellular influences. J. Neurophysiol., 83: 971983.

PIMENTEL-SOUZA F. \& SIQUEIRA, A.L., 1992, Effect of external carbon dioxide concentration on the electric organ discharge frequency in the gymnotiform fish Apteronotus albifrons. Braz. J. Med. Biol. Res., 25: 175-180.

SANCHEZ-GALÁN, S., LINDE, A.R., IZQUIERDO, J.I. \& GARCIA-VAZQUEZ, E., 1998, Micronuclei and fluctuating asymmetry in brown trout (Salmo trutta): complementary methods to biomonitor freshwater ecosystems. Mutat. Res., 412: 219-225. doi: 10.1016/S1383-5718(97)00186-1.

SCHMIDT, W., 1975, The micronucleus test. Mutat. Res., 31: 9-15. SERRANO-GARCIA, L. \& MONTERO-MONTOYA, A., 2001, Micronuclei and chromatid buds are the result of related genotoxic events. Environ. Mol. Mutagen., 38: 38-45. doi: 10.1002/em.1048.

THOMAS, M., CHRETIEN, D., FLORION, A. \& TERVER, D., 1996, Real-time detection of potassium cyanide pollution in surface waters using electric organ discharges wave emitted by the tropical fish, Apteronotus albifrons. Environ. Technol., 17: 561-574. 
UDROIU, I., 2006, The micronucleus test in piscine erythrocytes. Aquat. Toxicol., 79: 201-204. doi:10.1016/j. aquatox.2006.06.013.

VILLELA, I.V., OLIVEIRA, I.M., SILVA, J. \& HENRIQUES, J.A.P., 2006, DNA damage and repair in haemolymph cells of golden mussel (Limnoperna fortunei) exposed to environmental contaminants. Mutat. Res., 605: 78-86. doi:10.1016/j. mrgentox.2006.02.006.

WETMORE, B.A., STRUVE, M.F., GAO, P., SHARMA, S., ALLISON, N., ROBERTS, K.C., LETINSKI, D.J., NICOLICH, M.J., BIRD, M.G. \& DORMAN, D.C., 2008, Genotoxicity of intermittent co-exposure to benzene and toluene in male CD-1 mice. Chem. Biol. Interact., 173: 166-178. doi:10.1016/j. cbi.2008.03.012

WHO (World Health Organization), 1993, Benzene. Environmental Health Criteria, Geneva, n.150.

WHYSNER, J., REDDY, M.V., ROSS, P.M., MOHAN, M. \& LAX, E.A., 2004, Genotoxicity of benzene and its metabolites. Mut. Res., 566: 99-130. doi:10.1016/S1383-5742(03)00053-X.

WIRZINGER, G., WELTJE, L., GERCKEN, J. \& SORDYL, H., 2007, Genotoxic damage in field-collected three-spined sticklebacks (Gasterosteus aculeatus L.): a suitable biomonitoring tool? Mutat. Res., 628: 19-30. doi:10.1016/j.mrgentox.2006.11.011. 